\title{
The Protection Role of Nano-Doped Zinc Oxide on F2-Isoprostane as Biomarkers of Oxidative Stress in STZ- Induced Diabetic Retinopathy in Male Rats
}

\author{
Soheir N Abd El-Rahman* \\ Department of Crops Technology Research, Food Technology Research Institute, Giza, Egypt \\ *Corresponding author: Soheir N Abd El-Rahman, Department of Crops Technology Research, Food Technology Research \\ Institute, Agricultural Research Center, Giza, Egypt
}

\section{ARTICLE INFO}

Received:

Published: 慧 September 24, 2020

Citation: Soheir N Abd El-Rahman. The Protection Role of Nano-Doped Zinc Oxide on F2-Isoprostane as Biomarkers of Oxidative Stress in STZ- Induced Diabetic Retinopathy in Male Rats. Biomed J Sci \& Tech Res 30(4)-2020. BJSTR. MS.ID.004995.

Keywords: Diabetic Retinopathy; Streptozotocin; $\mathrm{Cl}$ : ZnO nanoparticales; Isoprostanes (IsoPs); Oxidative Stress

\begin{abstract}
Oxidative stress (OS) has been suggested as one of basic mechanism behind the development of type 2 diabetes especially diabetic retinopathy (DR). Isoprostanes (IsoPs) are involved in type 2 diabetes and increased in pathological conditions associated with OS. Our present study was designed to prepare $\mathrm{Cl}$ : $\mathrm{ZnO}$ nano particles (Cl: $\mathrm{ZnONPs}$ ) and evaluate the effect of $\mathrm{ZnCl}_{2}$ and $\mathrm{Cl}$ : ZnONPs at ( 5 and $10 \mathrm{mg} / \mathrm{kg}$ bw) on retinal oxidative stress in STZ-induced diabetic rats. The male albino rats treated with one dose of streptozotocin $\left(60 \mathrm{mg} / \mathrm{kg}\right.$ bw). The diabetic rats were administrated $\mathrm{Zn} \mathrm{Cl}_{2}$ and $\mathrm{Cl}$ : $\mathrm{ZnONPs}$ ( 5 and $10 \mathrm{mg} / \mathrm{kg} \mathrm{bw}$ ) orally for 3 days. The results investigated that TEM of Cl: ZnONPs has average particle size $14.5-70 \mathrm{~nm}$. Serum insulin and SOD were decreased and serum glucose and IsoPs were increased significantly $(\mathrm{P} \leq 0.05) 72 \mathrm{~h}$ after treatment with STZ $(60 \mathrm{mg} / \mathrm{kg} \mathrm{bw})$ than other groups. A significant decreased $(\mathrm{P} \leq 0.05)$ in glucose and $\mathrm{F}_{2}$ IsoPs levels and significant increase in insulin and SOD levels were detected also in retina in STZ diabetic rats which treated with $\mathrm{ZnCl}_{2}$ and $\mathrm{Cl}$ : ZnONPs (5 and $10 \mathrm{mg} / \mathrm{kg}$ bw). Cl: $\mathrm{ZnONPs}(10 \mathrm{mg} / \mathrm{kg}$ bw $)+(60 \mathrm{mg} / \mathrm{kg}$ bw $)$ gave the best results compared to $\mathrm{ZnCl}_{2}(5$ and $10 \mathrm{mg} / \mathrm{kg}$ bw) + STZ and Cl: ZnONPs (5mg/kg bw) + STZ. In conclusion, Cl: ZnONPs have a highly protective effect against hyperglycemia and diabetic retinopathy oxidative stress, especially at $(10 \mathrm{mg} / \mathrm{kg}$ bw) dosage.
\end{abstract}

\section{Introduction}

Diabetes mellitus is a group of metabolic diseases in which has high blood sugar in person, either because the body does not produce enough insulin, or because cells do not respond to the insulin that is produced [1]. All over the world there are many people suffer from diabetes [2], approximately (25.9\%) [3]. Oxidative stress (OS) due to the imbalance between pro-oxidant/antioxidant status results in generation of reactive oxygen species (ROS) and free radicals or impaired antioxidant defense system [4], subsequent modification of biomolecules such as protein, lipids and nucleic acids. Excessive generation of ROS and free radicals have been implicated in a variety of pathological events such as ischemia-reperfusion injury, cardiovascular disease [5] hepatorenal syndrome [6], scleroderma [7], smoking [8], coronary reperfusion injury [9], atherosclerosis
[10], diabetes mellitus [11,12] and neurodegenerative disease. Oxidative stress appears to be an integral and possibly causative part of the pathogenesis of diabetic retinopathy. Compelling evidence has been provided that both insulin-dependent and non-insulin-dependent diabetic patients are under conditions of oxidative stress and that the complications of diabetes mellitus (thereafter indicated as diabetes) could be partially mediated by oxidative stress [13] and that peroxide formation is increased in elevated glucose solutions. [14,15] Oxidative damage of cellular membranes has been suggested as a common mechanism in many bio pathological conditions. It can be measured by either primary or secondary end products of peroxidation. [16] while secondary end products include thiobarbituric reactive substances (TBARS), 
F2-like products termed F2-isoprostanes (F2-IsoPs). [17,18] Increased levels of F2-IsoPs can be found in the plasma of patients affected with type I and type II diabetes [11,19] and in animal models of diabetes [20] and currently are used as in vivo indicators of lipid peroxidation $[11,13,21,22]$. Zinc (Zn) is the most abundant trace intracellular element required for several cellular processes, including cell proliferation, reproduction, immune function and defense against free radicals [23]. It plays an important role as an antioxidant, protects cellular components from oxidation, [24]an activator for more than three hundred enzymes in the body [25] and in different metabolic pathways including glucose metabolism. [26] Also, Zinc promotes hepatic glycogenesis through its actions on the insulin pathways, storage, secretion [27] and thus improves glucose utilization [28]. Due to its fast electron transfer capability, $\mathrm{ZnO}$ is a key material for fabrication of bio membranes, and enzymatic detective devices [29]. Many studies have addressed the importance of $\mathrm{ZnO}$ as an antioxidant and a therapeutic agent in several free radicals initiating systems $[26,30]$. Nano-ZnO is a product whose particle diameter is between 1 to $100 \mathrm{~nm}$. More recently, the study of $\mathrm{ZnO}$ nanoparticles is a very active area [31,32]. Umrani, and Paknikar, [33] reported that the antidiabetic effects of ZnONPs through induction of insulin, also, they proved the ability of ZnONPs for controlling of blood glucose in diabetic rats. Soheir et al. [34] investigate the useful effects of high dose of $\mathrm{F}: \mathrm{ZnO}$ and $\mathrm{Cl}: \mathrm{ZnO}$ nanoparticles in protection diabetic rats against hyperglycemia and retina against oxidative stress. There is only one study that monitored the effect of $\mathrm{Cl}$ : $\mathrm{ZnO}$ nanoparticles on diabetic rats, but there is not previous study carried out with $\mathrm{Cl}$ : $\mathrm{ZnO}$ nanoparticles on the role of iso prostane during diabetic rats. Therefore, this work designed to prepare $\mathrm{ZnO}$ nanoparticles doped with chlorine (Cl: ZnOPNs) and reviews the role of $\mathrm{ZnCl}_{2}$ and $\mathrm{Cl}$ : $\mathrm{ZnONPs}$ on $\mathrm{F} 2$ Iso prostane as biomarkers of oxidative stress in retinal in relation to type II diabetes in rats.

\section{Materials and Methods}

\section{Experimental}

The $\mathrm{ZnO}$ nanoparticles doped with chlorine was prepared by a chemical solution method from zinc acetate (ZnAc) and oxalic acid. The preparation is as follows: $20 \mathrm{~mL}$ of a $0.5 \mathrm{M}$ ethanolic solution of oxalic acid was added drop-by-drop to $20 \mathrm{~mL}$ of a $0.1 \mathrm{M}$ ethanolic solution of $\mathrm{ZnAc}$ under stirring and maintained at $60^{\circ} \mathrm{C}$ for $3 \mathrm{~h}$. Then $0.5 \mathrm{M}$ of aqueous solution of ammonium chloride $\left(\mathrm{NH}_{3} \mathrm{Cl}\right)$ was added to the above solution to get at $5 \% \mathrm{Cl} / \mathrm{Zn}$ ratio. A white precipitate was obtained, which was separated by filtration and washed with a mixture of 75:25 (water: ethanol). This precipitate was dried in an oven at a temperature of $100^{\circ} \mathrm{C}$ for $24 \mathrm{~h}$. The obtained precursor was finally calcined at $500^{\circ} \mathrm{C}$ for $2 \mathrm{~h}$, with a heating rate of $5^{\circ} \mathrm{C} / \mathrm{min}$. All the reagents used in the experiments were of analytical grade and used directly as purchased.

\section{Characterization}

The structure was analyzed by FTIR spectra (FTIRNicolet6700). Surface Morphology was analyzed by SEM (Quanta 3D FEG/ FEI) and TEM (JEOL, Tokyo, Japan) operating at $60 \mathrm{kV}$.

\section{Biological Methods}

Male albino adult rats (60 animals weighing $130 \mathrm{~g} \pm 5$ ) were obtained from the private market, Helwan, Giza, Egypt, then transported to Animal House of Ophthalmology Research Institute, Giza, Egypt. Rats were housed in individual cages with screen bottoms and fed on basal diet (corn starch $70 \%$, casein $10 \%$, corn seed oil $10 \%$, cellulose $5 \%$, salt mixture $4 \%$ and vitamins mixture 1\%) for ten days. After equilibration, rats were weighted and divided into six groups (ten animals per each) everyone was assigned to one of the six diet groups (G1: Negative Control (NC), G2: STZ-treated group that injected with a single ip dose of STZ $(60 \mathrm{mg} / \mathrm{kg} \mathrm{bw}), \mathrm{G} 3$ : treated group that received a single dose of STZ $(60 \mathrm{mg} / \mathrm{kg} \mathrm{bw})+$ single daily oral low dose of $\mathrm{ZnCl}_{2}(5 \mathrm{mg} / \mathrm{kg} \mathrm{b.w})$, G4: treated group that received a single dose of STZ ( $60 \mathrm{mg} / \mathrm{kg} \mathrm{b.w})$ + single daily low dose of Cl: ZnONPs ( $5 \mathrm{mg} / \mathrm{kg}$ b.w), G5: treated group that received a single dose of STZ $(60 \mathrm{mg} / \mathrm{kg} \mathrm{b.w})+$ single daily oral high dose of $\mathrm{ZnCl}_{2}(10 \mathrm{mg} / \mathrm{kg}$ b.w), G6: treated group that received a single dose of STZ $(60 \mathrm{mg} / \mathrm{kg} \mathrm{b.w})+$ single daily high dose of Cl:ZnONPs (10mg/kg bw). Rats were sacrificed at $0,24,48$, and $72 \mathrm{~h}$ after STZ treatment. Before the rats were sacrificed, blood was collected from the orbital sinus and serum was prepared and kept frozen at $-20^{\circ} \mathrm{C}$ until the time of assay. Each eye was immediately enucleated, the lens was removed, and the retina was gently peeled away from the pigment epithelium and placed in $500 \mathrm{ml}$ ice-chilled $10 \mathrm{mmol} / \mathrm{l}$ sodium phosphate buffer, $\mathrm{pH}$ 8.0.

\section{Measurements of Blood glucose and Insulin}

Blood glucose $(\mathrm{mg} / \mathrm{dL})$ was estimated by glucose oxidase method using the kit supplied by SPINREACT (Sant Estevade Bas, Girona, Spain) according to, [35] we measured blood glucose in all experimental animals before the beginning of the experimental procedures, after streptozotocin injection. After that, blood glucose was monitored in all experimental animals, and results were obtained at $0,24,48$ and $72 \mathrm{~h}$ of the experimental period. Serum insulin was measured using an insulin radio immunoassay kit.

\section{Superoxide Dismutase (SOD) and F2-Isoprostanes (F2- IsoPs) Assay}

The enzymatic activity of retinal SOD was measured as described by ohkuma et al. [36]. Retinal F2-IsoPs were measured using a competitive enzyme-linked immunoassay (ELISA) kit according to instructions (Cayman Chemical, Ann Arbor, MI) [37].

\section{Statistical Analysis.}

The results are represented as mean \pm SE and statistically 
analyzed by using one-way ANOVA. Accepted level of significance $(\mathrm{P} \leq 0.05)$.

\section{Results and Discussion}

\section{IR Spectra}

Figure 1 shows the FT-IR at sorption spectrum prepared sample (Cl: ZnONPs). The peak at $470 \mathrm{~cm}^{-1}$ is the characteristic distinct stretching vibration of zinc oxide. The broad absorption peak at $3400 \mathrm{~cm}^{-1}$ can be attributed to the characteristic absorption of hydroxyls group. These results agree with Soheir et al. [34]. They reported that the undoped $\mathrm{ZnO}$, an absorption peak is observed centered at $372 \mathrm{~nm}$ (3.33 eV), which is in good agreement with previously reported works of $\mathrm{ZnO}$ single crystals and $\mathrm{Cl}$ : ZnONPs.

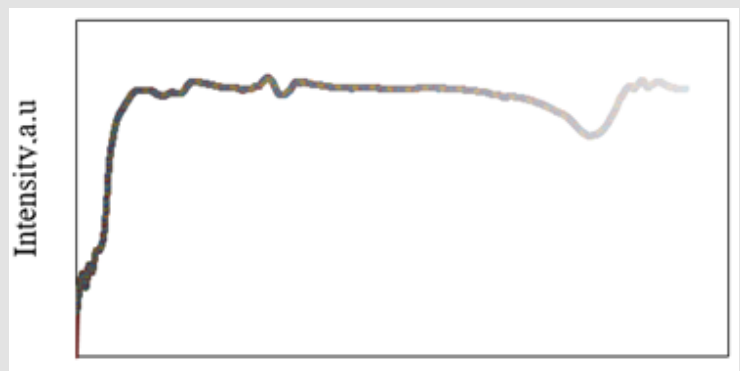

Wavenumber, $\mathrm{cm}^{-1}$

Figure 1: FTIR spectra of $\mathrm{Cl}$ : ZnONPs powder.

\section{Scanning Electron Microscopy (SEM)}

Figure 2 ( $\mathrm{a}$ and b) shows the SEM images of the Cl: ZnONPs powder prepared with chlorine doping. $\mathrm{Cl}$ : ZnONPs shows a rode shape. The results of this study agree with Soheir et al. [34] and they reported that the $\mathrm{ZnO}$ nano powders prepared with fluorine and chlorine and doping have average particle size 17.7 and $59.3 \mathrm{~nm}$, respectively.

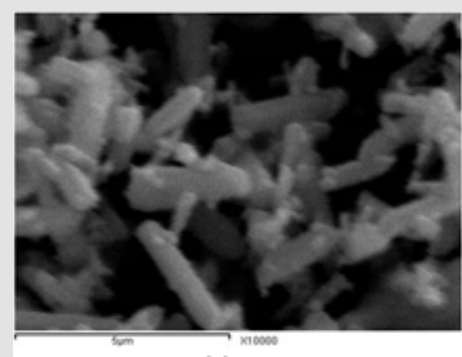

(a)

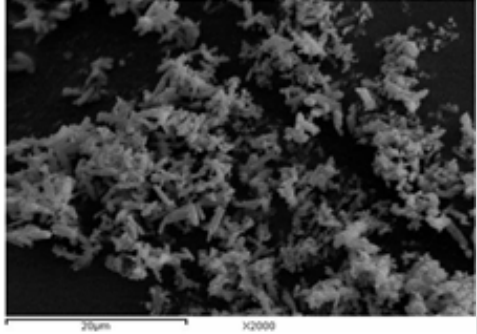

(b)

Figure 2: SEM spectra of $\mathrm{Cl}$ : ZnONPs powder.

\section{Transmission Electron Microscopy (TEM)}

Figure 3 shows the $\mathrm{Cl}$ : ZnONPs powder prepared with chlorine doping have average particle size 14.5-70.0nm.
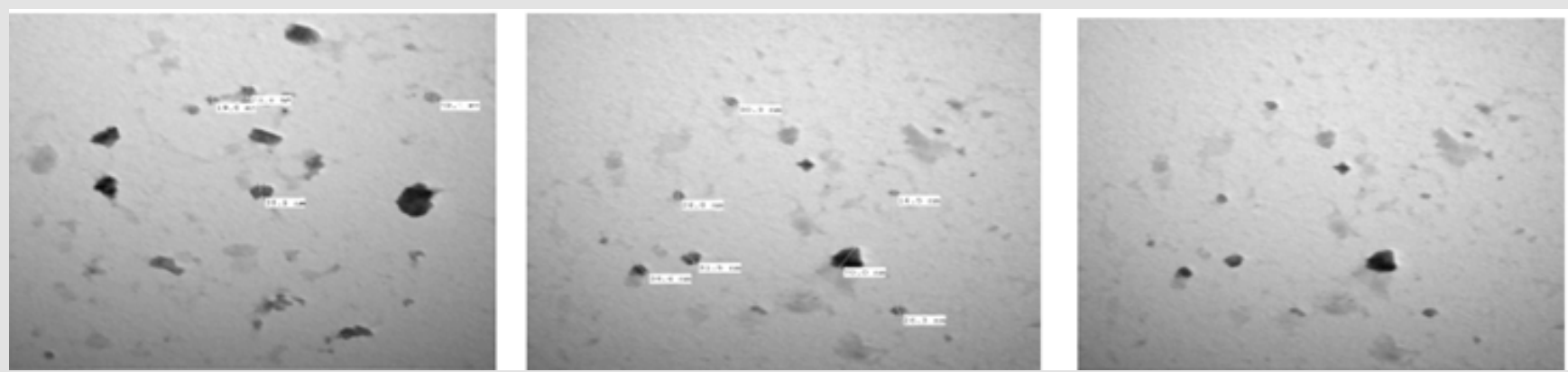

Figure 3: TEM spectra of $\mathrm{Cl}$ : ZnONPs powder. 


\section{Biochemical Markers}

Table 1 Shows the changes of serum glucose levels induced by $\mathrm{ZnCl}_{2}$ and $\mathrm{Cl}$ : ZnONPs in diabetic rats. Experimental groups treated by $\mathrm{ZnCl}_{2}$ and $\mathrm{Cl}$ : ZnONPs ( 5 and $10 \mathrm{mg} / \mathrm{kg}$ bw)for 3 days, showed a significant $(\mathrm{P} \leq 0.05)$ decreased in serum glucose levels, it found to be $(138.022,116.094 \mathrm{mg} / \mathrm{dl}),(117.962,102.964 \mathrm{mg} / \mathrm{dl})$ at 5 and 10 $\mathrm{mg} / \mathrm{kg} \mathrm{bw}$ ), respectively after $72 \mathrm{~h}$. Additionally, Cl: ZnONPs (10mg/ $\mathrm{Kg} \mathrm{bw})+\mathrm{STZ}(60 \mathrm{mg} / \mathrm{kg}$ bw) treated group results were close to normal values that showed in NC group. This showed a great antidiabetic activity of zinc oxide nanoparticles, as zinc has been elucidated to be a potent metal that improves glucose utilization and metabolism through its potent influence on enhancement of hepatic glycogenesis through actions on the insulin signaling pathway [34].

Table 1: Effect of $\mathrm{ZnCl}_{2}$ and $\mathrm{Cl}: \mathrm{ZnONPs}$ ( 5 and $10 \mathrm{mg} / \mathrm{Kg}$ bw) on Serum glucose concentration in diabetic rats.

\begin{tabular}{|c|c|c|c|c|}
\hline \multirow[b]{2}{*}{ Treatments } & \multicolumn{4}{|c|}{ Glucose (mg/dl) } \\
\hline & $\mathbf{O h}$ & $24 \mathrm{~h}$ & $48 h$ & $72 \mathrm{~h}$ \\
\hline G1 (NC) & $94.080^{\mathrm{b}} \pm 0.078$ & $94.808^{\mathrm{d}} \pm 0.121$ & $93.572^{\mathrm{f}} \pm 0.169$ & $94.932^{f} \pm 0.099$ \\
\hline $\mathrm{G} 2(\mathrm{PC})$ & $93.986^{\mathrm{b}} \pm 0.062$ & $154.392^{\mathrm{a}} \pm 0.615$ & $203.278^{\mathrm{a}} \pm 0.524$ & $379.524^{\mathrm{a}} \pm 0.474$ \\
\hline G3 & $94.556^{\mathrm{a}} \pm 0.124$ & $101.602^{\mathrm{b}} \pm 0.175$ & $141.104^{\mathrm{b}} \pm 0.272$ & $138.022^{\mathrm{b}} \pm 0.154$ \\
\hline G4 & $93.160^{c} \pm 0.257$ & $101.602^{\mathrm{b}} \pm 0.175$ & $109.184^{c} \pm 0.287$ & $116.094^{\mathrm{c}} \pm 0.272$ \\
\hline G5 & $94.178^{\mathrm{ab}} \pm 0.171$ & $97.040^{c} \pm 0.048$ & $121.104^{\mathrm{d}} \pm 0.272$ & $117.962^{\mathrm{d}} \pm 0.045$ \\
\hline G6 & $94.002^{\mathrm{b}} \pm 0.015$ & $95.380^{\mathrm{d}} \pm 0.192$ & $97.654^{\mathrm{e}} \pm 0.208$ & $102.964^{\mathrm{e}} \pm 0.039$ \\
\hline LSD & 0.417 & 0.840 & 0.908 & 0.693 \\
\hline
\end{tabular}

$\mathrm{G} 1(\mathrm{NC})=$ Negative control, G2 $(\mathrm{PC})=$ positive control, G3 = STZ + ZnCl $2(5 \mathrm{mg} / \mathrm{kg}$ bw), G4 = STZ + Cl: ZnONPs $(5 \mathrm{mg} / \mathrm{kg}$ bw $), \mathrm{G} 5=$ $\mathrm{STZ}+\mathrm{ZnCl}_{2}(10 \mathrm{mg} / \mathrm{kg}$ bw $), \mathrm{G} 6=\mathrm{STZ}+\mathrm{Cl}: \mathrm{ZnONPs}(10 \mathrm{mg} / \mathrm{kg}$ bw $)$

Our results revealed that $\mathrm{ZnCl}_{2}$ and $\mathrm{Cl}$ : ZnONPs (5 and 10mg/ $\mathrm{Kg} \mathrm{bw})+\mathrm{STZ}(60 \mathrm{mg} / \mathrm{Kg} \mathrm{bw})$ were significantly $(\mathrm{P} \leq 0.05)$ increased serum insulin level (290.40, $328.40 \mathrm{uIV} / \mathrm{ml}),(310.40,369.80 \mathrm{uIU} /$ $\mathrm{ml}$ ) at (5 and $10 \mathrm{mg} / \mathrm{kg} \mathrm{bw}$ ), respectively, compared to (PC) (177.40 $\mathrm{uIU} / \mathrm{ml}$ ) (Table 2). The serum insulin levels were significantly decreased in the diabetic group compared to the control group [38]. This results may be due to zinc could enhance the glucose stimulated insulin secretion from rat isolated pancreatic islets [40] Umrani and Paknikar [33] demonstrated that ZnONPs did not possess the risk of hypoglycemia in living organisms so it can act as an insulin secretor/due to accumulation of zinc in the secretory vesicle of $\mathrm{B}$ cells using transporter 8 [40]. Zinc transporters are also identified in adipose tissues and liver [34,41]. Treatment with ZnONPs. induced a significant increase in the serum insulin levels compared to the
Alkaladi et al. [31] showed a great reduction in blood glucose level in diabetic groups treated with ZnONPs, SNPs and insulin. However, ZnONPs induce more reduction than SNP. Rehal et al. [38] reported that at 30, 60, 90 and $120 \mathrm{~min}$, the plasma glucose levels in the STZinduced rats were treated with Vildagliptin, ZnONPs, and various combinations of the two, groups, for 7 weeks showed significant improvements compared to the diabetic group (group II). The maximum improvement in the reduced plasma glucose levels was observed in the rats treated with the combination therapy (Vildagliptin plus $10 \mathrm{mg} / \mathrm{kg} / \mathrm{d}$ ZnONPs, group IIIh) compared to diabetic group and the other treated groups [38]. Also, a great reduction in blood glucose level in diabetic groups treated with low and high dose of F: ZnONPs and Cl: ZnONPs, it found to be 119.03, $117.10,108.97$ and $103.97 \mathrm{mg} / \mathrm{dl}$ after $72 \mathrm{~h}$, respectively [34].

Table 2: Effect of $\mathrm{ZnCl}_{2}$ and $\mathrm{Cl}: \mathrm{ZnONPs}(5$ and $10 \mathrm{mg} / \mathrm{Kg}$ bw)on Serum Insulin concentration in diabetic rats.

\begin{tabular}{|c|c|c|c|c|}
\hline \multirow{2}{*}{ Time } & \multicolumn{4}{|c|}{ Insulin (uIU/ml) } \\
\cline { 2 - 5 } & $\mathbf{0 h}$ & $\mathbf{2 4} \mathbf{h}$ & $\mathbf{4 8 ~ h}$ & $\mathbf{7 2} \mathbf{~ h}$ \\
\hline Treatments & & $476.00^{\mathrm{a}} \pm 1.08$ & $475.40^{\mathrm{a}} \pm 1.45$ & $480.60^{\mathrm{a}} \pm 2.71$ \\
\hline G1 (NC) & $471.40^{\mathrm{bc} \pm 0.91}$ & $336.80^{\mathrm{e}} \pm 0.56$ & $205.60^{\mathrm{f}} \pm 0.58$ & $177.40^{\mathrm{f}} \pm 0.91$ \\
\hline G2 (PC) & $478.60^{\mathrm{a}} \pm 1.01$ & $354.00^{\mathrm{d}} \pm 0.30$ & $303.80^{\mathrm{e}} \pm 0.35$ & $290.40^{\mathrm{e}} \pm 0.22$ \\
\hline G3 & $469.20^{\mathrm{c}} \pm 0.71$ & &
\end{tabular}




\begin{tabular}{|c|c|c|c|c|}
\hline G4 & $474.00^{\mathrm{b}} \pm 0.98$ & $394.00^{\mathrm{c}} \pm 0.30$ & $367.00^{\mathrm{c}} \pm 1.28$ & $328.40^{\mathrm{c}} \pm 0.22$ \\
\hline G5 & $477.00^{\mathrm{a}} \pm 0.93$ & $394.40^{\mathrm{c}} \pm 0.22$ & $343.40^{\mathrm{d}} \pm 0.38$ & $310.40^{\mathrm{d}} \pm 0.22$ \\
\hline G6 & $471.60^{\mathrm{bc}} \pm 1.27$ & $415.20^{\mathrm{b}} \pm 0.78$ & $389.00^{\mathrm{b}} \pm 4.51$ & $369.80^{\mathrm{b}} \pm 1.05$ \\
\hline LSD & 2.924 & 1.861 & 5.960 & 3.700 \\
\hline
\end{tabular}

$\mathrm{G} 1(\mathrm{NC})=$ Negative control, G2 $(\mathrm{PC})=$ positive control, G3 = STZ + ZnCl $2(5 \mathrm{mg} / \mathrm{kg} \mathrm{bw}), \mathrm{G} 4=\mathrm{STZ}+\mathrm{Cl}: \mathrm{ZnONPs}(5 \mathrm{mg} / \mathrm{kg}$ bw $), \mathrm{G} 5=$ $\mathrm{STZ}+\mathrm{ZnCl}_{2}(10 \mathrm{mg} / \mathrm{kg}$ bw), G6 = STZ + Cl: ZnONPs $(10 \mathrm{mg} / \mathrm{kg}$ bw)

Isoprostanes in contrast to lipid hydroperoxides, are chemically stable end products of lipid peroxidation, and the measurement of their levels in plasma or urine may permit a sensitive and specific method for detection of lipid oxidative damage in vivo [22]. In the present study the retinal F2-IsoPs levels were significantly $(\mathrm{P} \leq 0.05)$ increased in the diabetic group $(0.7162 \mathrm{pg} / \mathrm{ml}$ bw) compared to the NC $(0.2762 \mathrm{pg} / \mathrm{ml}$ bw) after $72 \mathrm{~h}$ (Table 3). Treatment with $\mathrm{ZnCl} 2$ and $\mathrm{Cl}$ : ZnONPs (5 and 10mg/kg bw) + STZ (60mg/Kg bw) induced a significantly decreased of F2-IsoPs the retina levels compared to (PC). The results of $\mathrm{Cl}$ : ZnONPs $(10 \mathrm{mg} / \mathrm{kg}$ bw) + STZ $(60 \mathrm{mg} / \mathrm{kg}$ bw) was close to normal value that showed in NC group (Table 3). Increase in plasma level of total $\mathrm{F}_{2}$-IsoPs in type 2 diabetic nephropatic patients $(P \leq 0.01)$ with respect to controls
[43]. Increased F2-IsoPs synthesis during diabetes appears to be responsible in part for the increase in renal TGF- $\beta, \alpha$ well-known mediator of diabetic nephropathy [6].

Plasma $\mathrm{F}_{2}$-IsoPs levels in STZ-induced diabetic rats were significantly higher than in nondiabetic animals [44]. $\mathrm{ZnCl}_{2}$ and $\mathrm{Cl}$ : ZnONPs (5 and $10 \mathrm{mg} / \mathrm{kg}$ bw) +STZ (60mg/kg bw) treatment to STZ-induced diabetic rats are shown in Table 4. The results show significantly $(\mathrm{P} \leq 0.05)$ increased in retina SOD activity $(16.29,21.95$ $\mathrm{U} / \mathrm{ml}),(17.15,24.12 \mathrm{U} / \mathrm{ml})$ after treatment with $(5$ and $10 \mathrm{mg} /$ $\mathrm{kg} \mathrm{bw}$ ), respectively for $72 \mathrm{hthan}$ PC group (11.31 U/ml). ZON treatment increased serum SOD and catalase activity, suggesting antioxidant effects [34].

Table 3: Effect of $\mathrm{ZnCl}_{2}$ and $\mathrm{Cl}: \mathrm{ZnONPs}$ ( 5 and $10 \mathrm{mg} / \mathrm{Kg}$ bw) on retinal F2-isoprostans concentration in diabetic rats.

\begin{tabular}{|c|c|c|c|c|}
\hline \multirow{2}{*}{$\begin{array}{l}\text { Time } \\
\text { Treatments }\end{array}$} & \multicolumn{4}{|c|}{ F2-isoprostant (pg/ml) } \\
\hline & $\mathbf{0 h}$ & $24 \mathrm{~h}$ & $48 h$ & $72 \mathrm{~h}$ \\
\hline G1 (NC) & $0.2776^{a} \pm 0.001$ & $0.2750^{\mathrm{e}} \pm 0.000$ & $0.2762^{\mathrm{e}} \pm 0.001$ & $0.2762^{\mathrm{e}} \pm 0.001$ \\
\hline G2 (PC) & $0.2766^{\mathrm{a}} \pm 0.002$ & $0.5622^{\mathrm{a}} \pm 0.003$ & $0.6622^{\mathrm{a}} \pm 0.003$ & $0.7162^{\mathrm{a}} \pm 0.003$ \\
\hline G3 & $0.2758^{a} \pm 0.002$ & $0.3620^{\mathrm{b}} \pm 0.003$ & $0.3652^{\mathrm{b}} \pm 0.001$ & $0.3282^{b} \pm 0.003$ \\
\hline G4 & $0.2762^{\mathrm{a}} \pm 0.002$ & $0.3044^{\mathrm{c}} \pm 0.002$ & $0.3038^{c} \pm 0.001$ & $0.3048^{c} \pm 0.002$ \\
\hline G5 & $0.2774^{\mathrm{a}} \pm 0.001$ & $0.2942^{\mathrm{d}} \pm 0.002$ & $0.2956^{\mathrm{d}} \pm 0.001$ & $0.2952^{\mathrm{d}} \pm 0.001$ \\
\hline G6 & $0.2748^{\mathrm{a}} \pm 0.001$ & $0.2724^{\mathrm{e}} \pm 0.002$ & $0.2760^{\mathrm{e}} \pm 0.001$ & $0.2764^{\mathrm{e}} \pm 0.001$ \\
\hline LSD & 0.004 & 0.006 & 0.005 & 0.006 \\
\hline
\end{tabular}

$\mathrm{G} 1(\mathrm{NC})=$ Negative control, G2 $(\mathrm{PC})=$ positive control, G3 = STZ + ZnCl $2(5 \mathrm{mg} / \mathrm{kg}$ bw), G4 = STZ + Cl: ZnONPs $(5 \mathrm{mg} / \mathrm{kg}$ bw $), \mathrm{G} 5=$ $\mathrm{STZ}+\mathrm{ZnCl}_{2}(10 \mathrm{mg} / \mathrm{kg}$ bw $), \mathrm{G} 6=\mathrm{STZ}+\mathrm{Cl}: \mathrm{ZnONPs}(10 \mathrm{mg} / \mathrm{kg}$ bw $)$

Table 4: Effect of $\mathrm{ZnCl}_{2}$ Effect of $\mathrm{ZnCl}_{2}$ and and $\mathrm{Cl}$ : $\mathrm{ZnONPs}(5$ and $10 \mathrm{mg} / \mathrm{Kg}$ bw) on retinal SOD concentration in diabetic rats.

\begin{tabular}{|c|c|c|c|c|}
\hline \multirow{2}{*}{ Time } & \multicolumn{3}{|c|}{ SOD (U/ml) } \\
\cline { 2 - 5 } Treatments & $\mathbf{0 h}$ & $\mathbf{2 4} \mathbf{h}$ & $\mathbf{4 8 ~ h}$ & $\mathbf{7 2} \mathbf{h}$ \\
\hline G1 (NC) & $25.56^{\mathrm{a}} \pm 0.2$ & $25.36^{\mathrm{a}} \pm 0.2$ & $25.24^{\mathrm{a}} \pm 0.17$ & $25.09^{\mathrm{a}} \pm 0.03$ \\
\hline G2 (PC) & $25.36^{\mathrm{ab} \pm 0.17}$ & $20.19^{\mathrm{f}} \pm 0.03$ & $14.22^{\mathrm{f}} \pm 0.02$ & $11.31^{\mathrm{f}} \pm 0.17$ \\
\hline G3 & $25.08^{\mathrm{bc}} \pm 0.07$ & $21.04^{\mathrm{e}} \pm 0.02$ & $17.63^{\mathrm{e}} \pm 0.08$ & $16.29^{\mathrm{e}} \pm 0.11$ \\
\hline G4 & $25.17^{\mathrm{abc}} \pm 0.05$ & $22.47^{\mathrm{c}} \pm 0.04$ & $19.32^{\mathrm{c}} \pm 0.04$ & $21.95^{\mathrm{c}} \pm 0.15$ \\
\hline G5 & $24.93^{\mathrm{c}} \pm 0.13$ & $21.81^{\mathrm{d}} \pm 0.12$ & $18.94^{\mathrm{d}} \pm 0.05$ & $17.15^{\mathrm{d}} \pm 0.09$ \\
\hline G6 & $24.82^{\mathrm{c}} \pm 0.14$ & $24.38^{\mathrm{b}} \pm 0.23$ & $23.57^{\mathrm{b}} \pm 0.23$ & $24.12^{\mathrm{b}} \pm 0.02$ \\
\hline LSD & 0.399 & 0.392 & 0.360 & 0.320 \\
\hline
\end{tabular}

$\mathrm{G} 1(\mathrm{NC})=$ Negative control, G2 $(\mathrm{PC})=$ positive control, G3 = STZ + ZnCl2 (5mg/kg bw), G4 = STZ + Cl: ZnONPs (5mg/kg bw), G5 = $\mathrm{STZ}+\mathrm{ZnCl} 2(10 \mathrm{mg} / \mathrm{kg}$ bw) $, \mathrm{G} 6=\mathrm{STZ}+\mathrm{Cl}: \mathrm{ZnONPs}(10 \mathrm{mg} / \mathrm{kg}$ bw $)$ 


\section{Conclusion}

Based on our results, we can conclude that $\mathrm{ZnCl}_{2}$ and $\mathrm{Cl}$ : $\mathrm{ZnONPs}$ lead to activation of insulin mechanism of action and induction its synthesis. Cl: ZnONPs + STZ incresead SOD and decreased $\mathrm{F}_{2}$ IsoPs activates significantly ( $\mathrm{P} \leq 0.05$ ). Furthermore, the results elucidated the beneficial effects of high dose of $\mathrm{Cl}$ : ZNONPs gave the best results protection retinal against oxidative stress and controlling hyperglycemia.

\section{Acknowledgement}

The author is grateful for the assistance of the Field Crop Technology Research Department, Food Technology Research Institute, Agricultural Research Center, Giza, Egypt. We gratefully acknowledge the assistance of the animal house of Ophthalmology Research Institute, Giza, Egypt.

\section{References}

1. Wild S, Roglic G, Green A, Sicree R, King H (2004) Global prevalence of diabetes: estimates for the year 2000 and projections for 2030. Diabetes Care 27(5): 1047-1053.

2. Lin Y, Sun Z (2010) Current views on type 2 diabetes. J Endocrinol 204(1): 1-11.

3. Yeğin S, Mert N (2013) Investigation on the HbA1c, MDA, GSH-Px and SOD Levels in Experimentally Diabetic Rats. YYU Veteriner Fakultesi Dergisi 24(2): 51-54.

4. Pfeiffer A, Schatz H (1995) Diabetic microvascular complications and growth factors. Exp. Clin. Endocrinol. Diabetes 103(1): 7-14.

5. Kowluru RA, Kennedy A (2001) Therapeutic potential of anti-oxidants and diabetic retinopathy. Opin. Investig. Drugs 10(9): 1665-1676.

6. Halliwell B, Gutteridge JMC (2005) Free radicals in Biology and Medicine, 3rd (Edn), Clarendon Press, Oxford NUKLEONIKA 3: 67-76.

7. Morrow JD, Moore KP, Awad JA, Ravenscraft MP (1993) Marked over production of non-cyclooxygenase derived prostanoids (F2isoprostanes) in the strepto hepatorenal syndrome. J Lipid Mediat 6(13): 417-420.

8. Stein CM, Tanner SB, Awad JW, Roberts J, Morrow J (1996) Evidence of free radical-mediated injury (isoprostane overproduction) in scleroderma. Arthritis Rheumm 39(7): 1146-1150.

9. Morrow JA, Frei B, Longmire AW, Gaziano J, Lynch S, et al. (1995) Increase in circulating products of lipid peroxidation (F2-isoprostanes) in smokers: Smoking as a cause of oxidative damage. N Engl J Med 332(18): 1198-1203.

10. Delanty N, Reilly MP, Pratico D, Lawson JA, McCarthy JF, et al. (1997) 8-EpiPGF2 alpha generation during coronary reperfusion: A potential quantitative marker of oxidant stress in vivo. Circulation 95(11): 24922499.

11. Patrono C, Fiztgerald G (1997) Isoprostanes: Potential markers of oxidant stress in atherothrombatic disease. Arterioscler Thromb Vasc 17: 2309-2315.

12. DavI G, Ciabattoni G, Consoli A, Mezzetti A, Falco A, et al. (1999) In vivo formation of 8-iso-prostaglandin F2 alpha and platelet activation in diabetes mellitus: Effects of improved metabolic control and vitamin $\mathrm{E}$ supplementation. Circulation 99(2): 224-229.

13. Laight D, Kengatharan K, Gopaul N, Anggard E, Carrier M (1998) Investigation of oxidant stress and vasodepression to glyceryl trinitrate in the obese Zucker rat in vivo. Br J Pharmaco l 125(4): 895-901.
14. Davı G, Falco A, Patrono C (2005) Lipid peroxidation in diabetes mellitus. Antioxid Redox Signal 7: 256-268.

15. Hunt J, Smith C, Wolf S (1990) Autoxidative glycosilation and possible involvement of peroxides and free radicals in LDL modification by glucose. Diabetes 39(11): 1420-1424.

16. Trachtman H, Futterweit S, Maesaka J, Ma C, Valderrama E, et al. (1995) Taurine ameliorates chronic streptozotocin-induced diabetic nephropathy in rats. Am J Physio l 269(3): F429-F438.

17. Subramanian K, Sekaran M, Rajes Q, Ikram S (2009) $F_{2}$ Isoprostanes as Novel Biomarkers for Type2 Diabetes: A Review. J Clin Biochem Nutr 45: $1-8$.

18. Halliwell B, Grootveld M (1978) The measurement of free radical reactions in humans. FEBS Lett 213(1): 9-14.

19. Morrow J, Harris T, Roberts L (1990) Non cyclooxygenase oxidative formation of a series of novel prostaglandins: analytical ramifications for measurement of eicosanoids. Anal. Biochem 184(1): 1-10.

20. Gopaul N, Angaard E, Mallet A, Betteridge D, Wolf SP, et al. (1995) Plasma 8-epi-PGF2a levels are elevated in individuals with non-insulin dependent diabetes mellitus. FEBS Lett 368(2): 225-229.

21. Tada H, Ishii H, Isogai S (1997) Protective effect of d-alpha-tocopherol on the function of human mesangial cells exposed to high glucose concentrations. Metabolism 46(7): 779-784.

22. Roberts L, Morrow J (2000) Measurement of F2-isoprostanes as an index of oxidative stress in vivo. Free Radic Biol Med 28(4): 505-513.

23. Basu S (2004) Isoprostanes: novel bioactive products of lipid peroxidation. Free Radic Res 38(2): 105-122.

24. Powell S (2000) The antioxidant properties of zinc. Journal of Nutrition 130(5): 1447S-1454S.

25. Bruno R, Song Y, Leonard S, Mustacich D, Taylor A, et al. (2007) Dietary zinc restriction in rats alters antioxidant status and increases plasma $\mathrm{F} 2$ isoprostanes. The Journal of Nutritional Biochemistry 18(8): 509-518.

26. Haase H, Overbeck S, Rink L (2008) Zinc supplementation for the treatment or prevention of disease: current status and future perspectives. Exp. Gerontol 43(5): 394-408.

27. Hanna P, Kaiiska M, Jordan S, Mason R (1993) Role of metallothionine in zinc (II) and Chromium (III) mediated tolerance to carbon tetrachloride hepatotoxicity: evidence against a trichloromethyl radical-scavenging mechanism. Chem Res Toxicol 6(5): 711-717.

28. Chausmer A (1998) Zinc, insulin and diabetes. J Am Coll Nutr 17(2): 109115.

29. Jansen J, Karges W, Rink L (2009) Zinc and diabetes - clinical links and molecular mechanisms. J. Nutr.Biochem 20(6): 399-417.

30. Zhu X, Yuri I, Gan X, Suzuki I, Li G (2007) Electrochemical study of the effect of nano-zinc oxide on microperoxidase and its application to more sensitive hydrogen peroxide biosensor preparation. Biosens Bioelectron 22(8): 1600-1604.

31. Alkaladi A, Abdelazim A, Afifi M (2014) Antidiabetic activity of zinc oxide and silver nanoparticles on streptozotocin-induced diabetic rats. Int J Mol Sci 15: 2015-2023.

32. Yang Z, Liu Q (2008) Mutation-Selection Models of Codon Substitution and Their Use to Estimate Selective Strengths on Codon Usage. Mol Biol Evol 25(3): 568-579.

33. Umrani R, Paknikar K (2014) Zinc oxide nanoparticles show antidiabetic activity in streptozotocin-induced Type 1 and 2 diabetic rats. Nanomedicine (Lond) 9(1): 89-104.

34. Soheir N, Reda S, Sheikha M (2016) Synthesis and Characterization of Nano-doped Zinc Oxide and its Application as Protective Oxidative Changes in the Retina of Diabetic Rats. Journal of Diabetes \& Metabolism 7(7): 71000691. 
35. Tietz N (1995) Clinical guide to laboratory tests. $3^{\text {rd }}$ (Edn). Philadelphia. WB saunders 268-273.

36. Ohkuma N, Matsuo S, Tutsui M, Ohkawara A (1982) Superoxide dismutase in the epidermis Q4 (author's transl). Nippon Hifuka Gakkai Zasshi 92(5): 583-590

37. Morrow J, Roberts J (1997) The Isoprostanes: Unique Bioactive Products of Lipid Peroxidation. Progress in Lipid Research 36(1): 1-21.

38. Rehab A, Ashraf B, Sally A (2016) Zinc oxide nanoparticles and a standard antidiabetic drug restore the function and structure of beta cells in Type-2 diabetes. Biomedical \& Pharmacotherapy 84: 210-820.

39. Quesada I, Tuduri E, Ripoll C, Nadel A (2008) physiology of the pancreatic alpha-cell and glucagon secretion: role in glucose homeostasis and diabetes. J Endocrinol 199(1): 5-19.

40. Richards-Williams C, Contreras J, Berecek K, Schwiebert E (2008) Extracelluler ATP and zinc are co secreted with insulin and activate multiple P2X purinergic receptor channels expressed by islet beta cells to potentiate insulin secretion. Purinergic Signal 4(4): 393-405.

\section{ISSN: 2574-1241}

DOI: 10.26717/BJSTR.2020.30.004995

Soheir N Abd El-Rahman. Biomed J Sci \& Tech Res

(C) This work is licensed under Creative

Submission Link: https://biomedres.us/submit-manuscript.php
41. Rungby J (2010) Zinc transporters and diabetes. Diabetologia 53: 14491551.

42. Husssein S, EL-Senosil Y, El-Dawy K, Hind A (2014) Evaluation of Zinc Oxide Nanoparticles for Insulin, Insulin Receptors and Insulin Receptors Substrates Gene Expression in Streptozotocoin-Induced Diabetic Rats. Benha Veterinary Medical Journal AL 27(1): 166-174.

43. Vittori C, Cesare M, Maria S, Eduardo P, Stella C, et al. (2007) Oxidative Stress and cellular stress response in diabetic nephropathy. Cell stress \& Chaperones 12(4): 299-306.

44. Angl M, Karena M, Rizwan Z, Khan M, Valdivielso D, et al. (2000) $\mathrm{F}_{2}$-isoprostant mediate high glucose-induced TGF- $\beta$ synthesis and glomerular proteinuria in experimental type I diabetes. Kidney International 58: 1963-1972.

$\begin{array}{ll}\text { BIOMEDICAL } & \text { Assets of Publishing with us } \\ \text { RESEARCHES } & \text { - Global archiving of articles } \\ & \text { - Immediate, unrestricted online access } \\ & \text { - Rigorous Peer Review Process } \\ & \text { - Authors Retain Copyrights }\end{array}$

